\title{
BMJ Global Health Health and human rights are inextricably linked in the COVID-19 response
}

\author{
Sharifah Sekalala (D) , ${ }^{1}$ Lisa Forman, ${ }^{2}$ Roojin Habibi (D) ,3,4 \\ Benjamin Mason Meier (10 ${ }^{5}$
}

To cite: Sekalala S, Forman L, Habibi R, et al. Health and human rights are inextricably linked in the COVID-19 response. BMJ Global Health 2020;5:e003359. doi:10.1136/ bmjgh-2020-003359

\section{Handling editor Seye Abimbola}

Received 5 July 2020

Revised 9 August 2020

Accepted 19 August 2020
Check for updates

(C) Author(s) (or their employer(s)) 2020. Re-use permitted under CC BY-NC. No commercial re-use. See rights and permissions. Published by BMJ.

${ }^{1}$ Warwick Law School, University of Warwick, Coventry, UK ${ }^{2}$ Dalla Lana School of Public Health, University of Toronto, Toronto, Ontario, Canada ${ }^{3}$ Graduate Studies, Osgoode Hall Law School, Toronto, Ontario, Canada

${ }^{4}$ Global Strategy Lab, Toronto, Ontario, Canada

${ }^{5}$ Department of Public Policy, University of North Carolina at Chapel Hill, Chapel Hill, North Carolina, USA

Correspondence to Dr Benjamin Mason Meier; meierb@email.unc.edu

\section{ABSTRACT}

To mitigate the spread of COVID-19, governments throughout the world have introduced emergency measures that constrain individual freedoms, social and economic rights and global solidarity. These regulatory measures have closed schools, workplaces and transit systems, cancelled public gatherings, introduced mandatory home confinement and deployed largescale electronic surveillance. In doing so, human rights obligations are rarely addressed, despite how significantly they are impacted by the pandemic response. The norms and principles of human rights should guide government responses to COVID-19, with these rights strengthening the public health response to COVID-19.

\section{INTRODUCTION}

Human rights are fundamentally linked to global health in the context of the COVID-19 pandemic. The HIV/AIDS pandemic first underscored that rights-based approaches are one of the most effective paths to achieving public health, and this inextricable linkage between health and human rights has evolved over 30 years to provide a foundation for the COVID-19 response. ${ }^{1}$ Human rights provide a universal framework for advancing global health with justice, transforming moral imperatives into legal entitlements in key domains relevant to COVID-19. Rather than viewing human rights as placing unjustifiable restrictions on public health measures, they should be acknowledged as crucial to public health responses that employ rationality, proportionality and accountability, build public trust through transparency and participation, and prioritise the safety and protection of vulnerable and marginalised populations.

This article examines how human rights are central to three interconnected domains of COVID-19 responses: (1) the restriction of individual rights to protect public health, (2) the realisation of the right to health and its underlying determinants such as social security, food, water, housing and education in the context of health system responses
Summary box

There is an inextricable linkage between health and human rights, first identified in the early response to the HIV/AIDS pandemic, which has evolved over 30 years to provide a human rights foundation for the COVID-19 response.

- Human rights should guide government responses to COVID-19, strengthening the public health response to COVID-19 by: framing restrictions on individual liberties, managing COVID-19's impacts on medical care, public health and social and economic rights, and realising global solidarity through international collaboration and assistance.

- Many governments have introduced emergency laws in response to COVID-19 that restrict individual rights, including limitations on the freedom of movement through home confinement and limitations on the right to privacy through public health surveillance.

-While pandemics may require restrictions of individual rights to protect public health, these limitations must be necessary (following proper scientific evidence), proportionate (to the public health threat and time limited) and non-arbitrary (non-discriminatory).

- To ensure that public health measures employ a rights-based approach to health, governments must prioritise protecting the most vulnerable people in society through transparent policymaking and public participation.

- Beyond respect for individual liberties, states also bear obligations under the human right to health to ensure available, accessible, acceptable and good quality health responses to prevent and treat COVID-19.

- A wide range of economic and social rights are necessary to support underlying determinants of health through periods of physical distancing, including rights to work, social security, housing, food, water and sanitation.

- Governments have shared responsibilities to provide international assistance and collaboration to realise access to food, essential supplies, and testing and medical support in overcoming the COVID-19 pandemic through global solidarity.

and physical distancing measures, and (3) the fulfilment of international obligations of collaboration and assistance. Looking to 
international human rights law, we apply human rights to assess state responses to COVID-19 and also explore how human rights could better support policy responses to COVID-19. We find that the social and economic inequalities illustrated by COVID-19 underscore a key proposition of international human rights law-that all human rights are universal, indivisible and interdependent. ${ }^{2}$ Based on these interconnected rights, we conclude that human rights should guide what governments do to protect those most at risk from discriminatory and harmful state responses to the pandemic-framing restrictions on individual liberties, managing COVID-19's impacts on medical care, public health and social and economic rights, and realising global solidarity through international collaboration and assistance.

\section{RESTRICTING RIGHTS UNDER EMERGENCY LAWS}

International human rights obligations do not cease within global pandemics; however, many governments have introduced laws that restrict rights by limiting travel, banning public gatherings and widening powers of detention and force on people failing to self-isolate. Drawing from the 1966 International Covenant on Civil and Political Rights, international human rights law offers principles to ensure that restrictions on individual rights to protect public health are not needlessly restrictive or harmful. Limitations of rights must be necessary (following proper scientific evidence), proportionate (to the public health threat and time limited) and nonarbitrary (non-discriminatory). ${ }^{3}$ The United Nations (UN) Secretary General has reiterated the need for a human rights approach, arguing that state responses can respect human rights and the rule of law through measures that are proportionate to immediate threats and do not go further than necessary. ${ }^{4}$ It is crucial to consider how this human rights balancing can be used to assess and guide policy responses to home confinement and public health surveillance.

\section{Limitations on freedom of movement through home confinement orders}

New emergency laws have come into force in many countries requiring that almost all individuals stay within given geographical areas or remain confined to their homes. China's lockdown of Wuhan and the wider Hubei Province confined about 60 million people to their homes. ${ }^{5}$ Other countries, including India, France, Italy, New Zealand, South Africa and Poland, have imposed nationwide lockdowns, save for 'essential workers' such as doctors, nurses, pharmacists, grocery cashiers, government workers and food delivery services. ${ }^{6}$ Governments have enforced these lockdowns with sanctions, including imprisonment, as in Australia, where leaving home without a 'reasonable excuse' can incur fines of up to $\$ A 11000$ or 6 months' imprisonment. ${ }^{7}$ In India and Uganda, impoverished populations in informal settlements have been threatened with violence by authorities. ${ }^{89}$ Some of these lockdowns have been partially or fully lifted, but they will likely be reimplemented as new outbreaks arise. While we do not dispute the public health necessity of lockdowns as a legitimate response to COVID-19, some of these measures (as in India and Uganda) use unnecessary and disproportionate force.

Other countries have imposed explicit human rights violations in responding to the COVID-19 crisis, most egregiously in Hungary's enactment of a state of emergency without a clear time limit, allowing the prime minister to rule by decree. ${ }^{10}$ In other countries, lockdowns have had more indirect human rights impacts: for example, in Panama, the pico y género rule, which allowed men to leave their homes to buy food/medications on certain days and women to do so during other days, has disproportionately impacted transgendered women. There have been multiple reports of police harassment of trans women who had gone out to buy foods on days when women could do so. ${ }^{11} 12$ Reinforcing existing societal fault lines through confinement orders, Myanmar and Russia have introduced lengthy prison sentences and incarcerated greater numbers of individuals from marginalised populations for violating COVID-19-related measures,${ }^{13}$ with overcrowding in prisons and detention centres inevitably increasing the potential for the rapid spread of COVID-19, worsened by substandard healthcare in prisons. Groups such as migrants and refugees are particularly vulnerable to discrimination: Nepalese and Thai citizens working abroad have found themselves in desperate circumstances when their governments denied them the right to return home during the pandemic. ${ }^{1415}$

Human rights principles offer a clear lens for assessing the legitimacy of such confinement measures. First, while many human rights can be derogated from (or limited) to protect public health, certain rights, such as the right to life, cannot. ${ }^{3}{ }^{16-18}$ Second, sanctions for violating home confinement and restricted movement orders should be proportionate to national threats of COVID-19 and should not be unduly punitive. The High Court of Kenya recently held that while curfews were lawful, the use of unreasonable force in its imposition was unlawful, finding that the police were liable for violating the rights to life and dignity of people who were alleged to have broken the curfew. Additionally, this case highlights the importance of judicial review of rights limitations. ${ }^{19}$ To ensure that such measures are not discriminatory or used as a weapon against minorities, governments must operate through transparent policymaking, engaging the participation of vulnerable populations as a basis to ensure rights realisation and public cooperation in emergency responses.

\section{Limitations on privacy through public health surveillance}

In their emergency public health responses, some states have drafted or relaxed data protection laws to monitor compliance with social distancing measures and facilitate disease surveillance. ${ }^{20} 21$ Through smartphone location data, Israel used emergency laws to introduce 
a surveillance programme using the national security agency to track potentially infected people $;{ }^{22}$ and South Korea released detailed identifying information on infected individuals through private apps, alerting users in their vicinity and leading to discrimination against elderly people. ${ }^{23}$ In China, all citizens must install phone software to predict health status, track and share locations with police and determine whether people can enter public spaces. ${ }^{24}$

In promoting contact tracing through digital tools, governments may also be intensifying inequalities, as many people may not have modern smartphones that support contact tracing technologies..$^{25}$ Thus, when the data collected through these apps and other technologies are used to inform decision-making processes, they may omit vulnerable groups in policymaking. In Argentina, for instance, the government adopted the CuidAR COVID-19 app to facilitate contact tracing; however, the policy did not consider that many people living in informal settlements (who are among the most vulnerable to COVID-19) do not have smartphones. ${ }^{26-28}$

Increased surveillance in a health emergency may be useful to support social distancing efforts as well as to inform epidemiological research to trace contacts of infected persons in responding to outbreaks. Yet, the expansion of surveillance technologies beyond traditional public health mechanisms heightens longer standing tensions between individual rights and collective interests. Without adequate safeguards to protect or at least minimise the impact on individual rights (such as privacy and freedom of movement), emerging surveillance technologies pose serious long-term risks to human rights. In line with the principle of proportionality under human rights law, all COVID-19 surveillance tools must be proven to be strictly necessary (based on epidemiological evidence), temporary and proportionate. Largescale data collection tools that do not identify individuals could meet those human rights requirements. ${ }^{29}$ Beyond deidentified data, governments should consider opt-in approaches first (as in Canada, Iceland and Italy, where people consent via apps for their data to be used for research).$^{30}$ International human rights law also requires governments to ensure that opt-in consents are not exploited by unnecessary extensions or used for profit by the private sector. ${ }^{31}$ Private corporate surveillance on behalf of governments should be time limited and not be normalised after the pandemic.

These examples of rights restrictions under emergency laws suggest several cross-cutting human rights principles to frame public health-related limitations of human rights: governments must prioritise protecting the most vulnerable people in society. Initiatives like social distancing and self-isolation will disproportionately affect vulnerable people, including the precariously employed, migrant populations and homeless. ${ }^{32}$ Before restraining individual liberties, states must be transparent in communicating the scientific advice informing decision-making. Governments must also enable public participation by vulnerable populations to the greatest extent possible, building trust among citizens, compliance with government rights restrictions and accountability for rights violations. ${ }^{33}$ Additionally, governments should ensure that even in times of crisis, there are restrictions on the circumstances under which state agents can use force, limiting the use of coercive measures such as fines and imprisonment to enforce public health objectives.

\section{FULFILLING THE RIGHT TO HEALTHCARE AND UNDERLYING DETERMINANTS OF HEALTH}

Beyond respect for individual liberties, states also hold duties to ensure adequate medical and public health responses to COVID-19 under rights to health and to underlying determinants of health, including work, social security, housing, food, water and sanitation. In 1946, states recognised in the WHO Constitution that 'the enjoyment of the highest attainable standard of health is one of the fundamental rights of every human being. ${ }^{34}$ Subsequently, the right to health has been elaborated repeatedly in international and regional human rights treaties. ${ }^{35-43}$ The International Covenant on Economic, Social and Cultural Rights (ICESCR) codifies the right to the highest attainable standard of physical and mental health, ${ }^{44}$ which has been authoritatively interpreted to create duties to ensure access to available, accessible, acceptable and good quality healthcare and to provide for underlying determinants of public health, including water, sanitation, food, housing, education and gender equality. ${ }^{45}$

\section{The right to available, accessible, acceptable and good quality healthcare}

COVID-19 has illustrated to many countries that their health systems are unable to withstand a prolonged health crisis. Many countries such as the UK, Italy, Spain and the USA are struggling to respond, partly due to years of budget cuts under austerity measures. ${ }^{46-51}$ As a result, they have struggled to source adequate diagnostic testing and personal protective equipment (PPE) to prevent disease transmission. ${ }^{52} 53$ Compounded by discrimination in healthcare settings, marginalised groups such as migrants and displaced persons, racial and ethnic minorities, women, sexual minorities, older persons, incarcerated populations and those living with HIV are particularly vulnerable to violations of the right to health. ${ }^{54}$ For example, the UN High Commissioner for Refugees has identified thousands of migrants at risk of further harm without adequate healthcare. Bosnian authorities, for instance, transferred thousands of migrants to a remote camp in Lipa, $25 \mathrm{~km}$ from the Croatian border, without access to healthcare. ${ }^{55}$ To comply with the right to health, states must ensure that access to appropriate COVID-related diagnostic testing and emergency healthcare for such groups is prioritised within healthcare policies, programmes and practices, and that states conduct human rights impact assessments to analyse the impacts 
of healthcare inequalities on vulnerable and marginalised groups.

Yet many countries have been unable to operationalise the right to health to enable available, accessible, acceptable and good quality PPE, diagnostic testing, contact tracing and healthcare services. ${ }^{56}$ Countries such as South Africa introduced a mass testing programme which was made free available to everyone, ${ }^{52}$ and in countries with health inequalities between public and private care (like Spain and the UK), private hospitals are being nationalised to ensure that all citizens have equitable access to treatment. ${ }^{57} 58$ However, in countries like the USA, those without medical insurance are being denied access to treatment or facing prohibitive user fees for basic COVID-19 treatment, resulting in inequitable mortality. ${ }^{59-61}$

\section{Rights relating to the underlying determinants of health}

Beyond the right to health in healthcare settings, other economic and social rights impact public health during periods of physical distancing, including rights to housing, social security, employment, food, water and sanitation. Widescale social distancing highlights existing vulnerabilities within economic systems: large numbers of people are employed in service and manufacturing sectors not amenable to social distancing; the growth in precarious work has threatened continuing income, with social security systems weakened and housing increasingly insecure and inadequate.$^{62}$ These underlying determinants to health, often reflected in other health-related human rights, must not be neglected amidst public health emergency measures. For those unable to work, social distancing disproportionately impacts vulnerable groups by harming the health of those who are poor, struggling to survive, homeless, or lacking food, water and sanitation. ${ }^{63}$ Women across the world have been particularly impacted by the COVID-19 crisis. Many women who were already less likely to be in secure work or have access to unemployment benefits are more likely to stay home and care for family based on discriminatory policies and gender norms. National lockdowns are particularly dangerous for women at risk of domestic violence, who cannot access domestic abuse shelters, with an exponential increase in domestic abuse during the timeline of the pandemic. $^{6465}$

The predominant policy response has been to facilitate economic bailouts of institutions and individuals to enable citizens to comply with social distancing while meeting basic needs. Businesses have received economic bailouts, cheap credit from central banks, altered tax laws and increased social security payments to support employees. ${ }^{66}$ Some governments have indemnified workers' wages to allow company closures for as long as necessary. ${ }^{67-70}$ Spain specifically cited constitutional rights when it allocated resources to a 'social shield' package, which included a moratorium on mortgage and utility payments for people unable to pay; increased unemployment benefits and social services for citizens most at risk, such as the elderly, disabled or those with low incomes; and the state acting as a payer of last resort to stave off mass lay-offs. ${ }^{71}$ Yet stimulus packages in France, Denmark, the UK and India did not explicitly mention social rights or address the plight of vulnerable groups, reinforcing a narrative of economic stimulus at the expense of the vulnerable. ${ }^{72}$ For instance, India's stimulus package only allocated food to vulnerable groups for 2 months, while South Africa gave out food parcels in ways that overlooked refugees and asylum seekers. Courts have stepped in to enforce rights amidst social distancing. In Malawi, the High Court instituted an injunction against the national lockdown because the government made insufficient provision to stop poor people from going hungry or being denied water and sanitation. ${ }^{73}{ }^{74} \mathrm{UN}$ Habitat is providing clean water to many citizens in informal settlements in many countries, ${ }^{75}$ and the South African government increased water and sanitation measures in high-density public areas, informal settlements and rural areas.

\section{INTERNATIONAL OBLIGATIONS: HUMAN RIGHTS OBLIGATION TO ASSIST}

To meet this global threat, the world will require a formidable shift towards global solidarity and shared responsibility. ${ }^{76}$ International assistance and collaboration to ensure access to food, essential supplies, and testing and medical support is a human rights imperative that will be crucial in overcoming this pandemic. Low-income countries will face unique obstacles to mitigating COVID-19, yet many isolationist laws in high-income countries have ignored this global emergency: the UK enacted laws to prevent exporting essential medicines, ${ }^{77}$ the European Union curbed exports of hospital supplies ${ }^{78}$ and the USA restricted PPE exports for healthcare staff. ${ }^{79}$ International sanctions against Iran, one of the world's worst-hit countries, have exacerbated dire shortages in medical supplies and humanitarian aid. ${ }^{80}$

Human rights law has long recognised an obligation of wealthy countries to assist low-income countries: since the adoption of the Universal Declaration of Human Rights, states have acknowledged that international cooperation is necessary to realise human rights. ${ }^{81}$ Through the ICESCR, states have bound themselves to international cooperation to progressively realise social and economic rights, including the right to health. ${ }^{44}$ This obligation of international assistance is extended by the International Health Regulations, which impose a duty to assist other nations in preventing disease. ${ }^{82}$

A failure to assist nations in need, denying necessary medical supplies or enforcing debt repayments that divert resources from essential services, would be short-sighted in controlling the pandemic and anathema to global solidarity. COVID-19 has illustrated that all countries are equally vulnerable to the spread of infectious diseases. Recognising this, some wealthy countries have directly supported low-income countries to address COVID-19, ${ }^{83}$ 
with other nations offering support through the UN's COVID-19 Global Humanitarian Response Plan, ${ }^{84}$ the UN Framework for the Immediate Socio-Economic Response to COVID-19 $9^{85}$ and the WHO COVID-19 Solidarity Response Fund. ${ }^{86}$

Several proposals at the international level could enable wealthy countries to meet their international obligations to assist low- and middle-income countries, with full funding of WHO essential to meeting the emergency needs of this response. The International Monetary Fund, working with WHO, has offered to suspend debt collection to support global health. ${ }^{87}$ On Costa Rica's initiative, the WHO launched a voluntary intellectual property pool for the sharing of COVID-19-related technologies and knowledge ${ }^{88}$ and low-income states have rallied behind a 'People's Vaccine' to ensure that prospective vaccines will be accessible to all. ${ }^{89}$

\section{CONCLUSION}

COVID-19 is an unprecedented global threat, and human rights should be at the core of the global response-as states have legally binding obligations to do so and there is evidence that human rights-based policies strengthen public health. Where human rights are inextricably linked to public health outcomes and interconnected in the COVID-19 response, governments should adopt laws that are proportionate, necessary and non-discriminatory towards society's most vulnerable members and should ensure that laws alleviate the worst impacts of the crisis on vulnerable groups. Moreover, the indivisibility of human rights, which the pandemic brings clearly to light, also highlights the need for better coordination among a siloed human rights community. Second, governments must be open and transparent and ensure participation so that people can assure accountability in decisionmaking. Lastly, global solidarity is essential and must integrate human rights: cross-border financing must be increased and any vaccine must be globally accessible. COVID-19 underscores that human rights are critical for effective public and global health. The terrible scale of this crisis offers an opportunity to radically rethink state obligations to safeguard health systems and prepare for the future.

Twitter Roojin Habibi @roojinh and Benjamin Mason Meier @BenjaminMMeier

Acknowledgements The authors are grateful to members of the Global Health Law Consortium, who provided helpful feedback in the development of this human rights analysis.

Contributors SS led the ideation, research and writing of this manuscript. LF, $\mathrm{RH}$ and BMM contributed in equal parts to the development of key sections of the manuscript, overall editing and responding to peer reviews and feedback. All coauthors signed off on final version of the manuscript.

Funding The authors have not declared a specific grant for this research from any funding agency in the public, commercial or not-for-profit sectors.

Competing interests None declared.

Patient consent for publication Not required.

Provenance and peer review Not commissioned; externally peer reviewed.

Data availability statement There are no data in this work.
Open access This is an open access article distributed in accordance with the Creative Commons Attribution Non Commercial (CC BY-NC 4.0) license, which permits others to distribute, remix, adapt, build upon this work non-commercially, and license their derivative works on different terms, provided the original work is properly cited, appropriate credit is given, any changes made indicated, and the use is non-commercial. See: http://creativecommons.org/licenses/by-nc/4.0/.

\section{ORCID iDs}

Sharifah Sekalala http://orcid.org/0000-0002-5434-5245

Roojin Habibi http://orcid.org/0000-0001-7948-0438

Benjamin Mason Meier http://orcid.org/0000-0002-9870-1387

\section{REFERENCES}

1 Mann JM, Gruskin S, Grodin MA, et al. Health and human rights: a reader. New York: Routledge, 1999: 11-18.

2 World Conference on Human Rights. Vienna Declaration and programme of action. United nations General assembly. un doc AV CONF 157/2312; 1993.

3 Commission on Human Rights. Siracusa principles on the limitation and Derogation provisions in the International covenant on civil and political rights. New York, 1984.

4 Guterres A. We are all in this together: human rights and COVID-19 response and recovery, 2020. Available: https://www.un.org/en/ un-coronavirus-communications-team/we-are-all-together-humanrights-and-covid-19-response-and [Accessed 7 Aug 2020].

5 Joles B. Voices from Hubei, two weeks into coronavirus lockdown, 2020. Available: https://www.aljazeera.com/news/2020/02/voiceshubei-weeks-lockdown-200207075046551.html [Accessed 7 Aug 2020].

6 Kaplan J, Frias L, McFall-Johnsen M. A third of the global population is on coronavirus lockdown-here's our constantly updated list of countries and restrictions. Business Insider. Available: https:// www.businessinsider.in/international/news/a-third-of-the-globalpopulation-is-on-coronavirus-lockdown-x2014-hereaposs-ourconstantly-updated-list-of-countries-and-restrictions/slidelist/ 75208623.cms [Accessed 7 Aug 2020].

7 Government Gazette No 65 of 30 March 2020. Nsw legislation, 2020 Available: https://gazette.legislation.nsw.gov.au/so/download.w3p? id=Gazette_2020_2020-65.pdf

8 Human Rights Watch. India: COVID-19 Lockdown puts poor at risk, 2020. Available: https://www.hrw.org/news/2020/03/27/india-covid19-lockdown-puts-poor-risk [Accessed 7 Aug 2020].

9 Kwalimwa D. Uganda: police shoot two on Bodaboda for defying Museveni COVID-19 order, 2020. Available: https://allafrica.com/ stories/202003300087.html [Accessed 7 Aug 2020].

10 Quinn C. Hungary's Orban Given Power to Rule By Decree With No End Date. Available: https://foreignpolicy.com/2020/03/31/hungarysorban-given-power-to-rule-by-decree-with-no-end-date/ [Accessed 7 Aug 2020].

11 Gonzalez Cabrera C. Panama's Gender-Based Quarantine Ensnares Trans Woman, 2020. Available: https://www.hrw.org/news/2020/ 04/02/panamas-gender-based-quarantine-ensnares-trans-woman [Accessed 7 Aug 2020].

12 Human Rights Watch. Myanmar: hundreds Jailed for Covid-19 violations, 2020. Available: https://www.hrw.org/news/2020/05/ 28/myanmar-hundreds-jailed-covid-19-violations [Accessed 7 Aug 2020].

13 Rainsford S. Russia includes jail terms to enforce crackdown, 2020. Available: https://www.bbc.com/news/world-europe-52109892 [Accessed 7 Aug 2020].

14 Ganguly M. Nepal Abandons migrant workers in fight against COVID-19, 2020. Available: https://www.hrw.org/news/2020/03/31/ nepal-abandons-migrant-workers-fight-against-covid-19 [Accessed 7 Aug 2020].

15 Quinley C. Thais left stranded overseas SLAM coronavirus policy confusion, 2020. Available: https://www.aljazeera.com/news/2020/ 04/thais-left-stranded-overseas-slam-coronavirus-policy-confusion200416072630213.html [Accessed 7 Aug 2020].

16 European Court of Human Rights. European Convention on Human Rights, Article 15(2). Available: https://www.echr.coe.int/Documents/ Convention_ENG.pdf [Accessed 7 Aug 2020].

17 International Covenant on Civil and Political Rights, Article 4(2), 1976. Available: https://www.ohchr.org/EN/Professionallnterest/ Pages/CCPR.aspx [Accessed 8 Aug 2020].

18 General Comment No. 29: states of emergency (article 4), 2001. Available: http://docstore.ohchr.org/SelfServices/FilesHandler. ashx?enc=6QkG1d\%2fPPRiCAqhKb7yhsjYoiCfMKolRv2FVa VzRkMjTnjRO\%2bfud3cPVrcM9YROiix49nIFOsUPO4oTG7R\% 
2fo7TSsorhtwUUG\%2by2PtsIYr5BldM8DN9shT8B8NpbsC\%2b7b ODxKR6zdESeXKjiLnNU\%2bgQ\%3d\%3d [Accessed 8 Aug 2020].

19 Law Society of Kenya v Hillary Mutyambai,, Inspector General National Policy Service \& 4 others. Petition 120 of 2020 (Covid 025), 2020. Available: http://kenyalaw.org/caselaw/cases/view/192748/ [Accessed 8 Aug 2020].

20 World Health Organization. Digital tools for COVID-19 contact tracing: annex: contact tracing in the context of COVID-19, 2020. Available: https://apps.who.int/iris/handle/10665/332265

21 OECD. Ensuring data privacy as we battle COVID-19, 2020. Available: https://www.oecd.org/coronavirus/policy-responses/ ensuring-data-privacy-as-we-battle-covid-19-36c2f31e/ [Accessed 8 Aug 2020].

22 Chachko E. The Israeli Supreme Court checks COVID-19 electronic surveillance, 2020. Available: https://www.lawfareblog.com/israelisupreme-court-checks-covid-19-electronic-surveillance [Accessed 8 Aug 2020].

23 Fahim K, Kim MJ, Hendrix S. Cellphone monitoring is spreading with the coronavirus. so is an uneasy tolerance of surveillance, 2020. Available: https://www.washingtonpost.com/world/cellphonemonitoring-is-spreading-with-the-coronavirus-so-is-an-uneasytolerance-of-surveillance/2020/05/02/56f14466-7b55-11ea-a311adb1344719a9_story.html [Accessed 8 Aug 2020].

24 China: Alipay health code APP controls movement in China, 2020. Available: http://privacyinternational.org/examples/3417/chinaalipay-health-code-app-controls-movement-china [Accessed 8 Aug 2020].

25 Beaunoyer E, Dupéré S, Guitton MJ. COVID-19 and digital inequalities: reciprocal impacts and mitigation strategies. Comput Human Behav 2020;111:106424.

26 Rodriguez-Ferrand G. Argentina. In: Regulating electronic means to fight the spread of COVID-19. New York: Law Library of Congress, 2020: 5-10. https://www.loc.gov/law/help/coronavirus-apps/ coronavirus-apps.pdf

27 Silver L. Smartphone Ownership Is Growing Rapidly Around the World, but Not Always Equally. Pew Research Center's Global Attitudes Project, 2019. Available: https://www.pewresearch.org/ global/2019/02/05/smartphone-ownership-is-growing-rapidlyaround-the-world-but-not-always-equally/ [Accessed 8 Aug 2020]

28 Jaime M. Argentina: 4 million people live in precarious conditions, 2020. Available: https://latinamericanpost.com/32361-argentina-4million-people-live-in-precarious-conditions [Accessed 8 Aug 2020].

29 Ní Aoláin F. Promotion and protection of all human rights, civil, political, economic, social and cultural rights, including the right to development, 2018. Available: https://primarysources. brillonline.com/browse/human-rights-documents-online/promotionand-protection-of-all-human-rights-civil-political-economicsocial-and-cultural-rights-including-the-right-to-development; hrdhrd99702016149 [Accessed 8 Aug 2020].

30 MIT Technology Review. Covid tracing Tracker. Available: https:// www.technologyreview.com/tag/covid-tracing-tracker/ [Accessed 8 Aug 2020].

31 Un special Rapporteur on the right to privacy, Task force on privacy and protection of health-related data. recommendation on the protection and use of health-related data, 2019. Available: https:// www.ohchr.org/Documents/Issues/Privacy/SR_Privacy/UNSRPhea IthrelateddataRecCLEAN.pdf [Accessed 9 Aug 2020].

32 Farha L. COVID-19 guidance note protection for those living in homelessness, 2020. Available: http://unhousingrapp.org/user/ pages/07.press-room/Guidance $\% 20$ Note $\% 20$ Homelessness $\%$ 20Actual\%20Final\%202\%20April\%202020[2].pdf [Accessed 8 Aug 2020].

33 Yamin AE, Habibi R. Human Rights and Coronavirus: What's at Stake for Truth, Trust, and Democracy? 2020. Available: https:// www.hhrjournal.org/2020/03/human-rights-and-coronaviruswhats-at-stake-for-truth-trust-and-democracy/ [Accessed 9 Aug 2020].

34 Constitution of the world Health organization, 1946 July 22, 14 UNTS 185

35 Un General assembly, universal Declaration of human rights, 10 December 1948, 217 A (III). Available: https://www.un.org/en/ universal-declaration-human-rights/index.html [Accessed 1 Apr 2020].

36 Constitution of the world Health organization, 1946. Available: https://apps.who.int/gb/bd/PDF/bd47/EN/constitution-en.pdf?ua=1 [Accessed 9 Aug 2020].

37 Un General assembly, universal Declaration of human rights, 10 December 1948, 217 A (III).

38 African charter on human and peoples rights adopted by the organisation of African unity 27 June 1981, entered into forced 21 October 1986
39 Additional Protocol to the American Convention on Human Rights in the Area of Economic, Social and Cultural Rights ("Protocol of San Salvador"), 16 November 1999, A-52 OAS TS 69, article 10.

40 European Social Charter adopted by the Council of Europe; the International Convention on the Elimination of All Forms of Racial Discrimination (ICERD), (UN 1969: article 5.e.iv).

41 Convention on the elimination of all forms of discrimination against women (CEDAW) (un 1979: article 12.1-2).

42 Convention on the rights of the child (CRC) (un 1989: article 24.1).

43 Convention on the rights of persons with disabilities (CRPD) (un 2008: articles 9, 25 and 26).

44 International Covenant on Economic, Social and Cultural Rights, Article 12(1) and 12(2). UN Office of the High Commissioner for Human Rights, 1976. Available: https://www.ohchr.org/en/ professionalinterest/pages/cescr.aspx [Accessed 9 Aug 2020]

45 Committee on Economic, Social and Cultural Rights. General Comment No. 14: the right to the highest attainable, paras, 2020. Available: https://www.refworld.org/pdfid/4538838d0.pdf

46 Hunter DJ. Covid-19 and the Stiff Upper Lip - The Pandemic Response in the United Kingdom. N Engl J Med 2020;382:e31.

47 Vize R. How the erosion of our public health system hobbled England's covid-19 response. BMJ 2020;369:m1934.

48 Prante FJ, Bramucci A, Truger A. Decades of tight fiscal policy have left the health care system in Italy III-Prepared to fight the COVID-19 outbreak. Inter Econ 2020;55:147-52.

49 Legido-Quigley H, Mateos-García JT, Campos VR, et al. The resilience of the Spanish health system against the COVID-19 pandemic. Lancet Public Health 2020;5:e251-2.

50 HD X, Basu R. How the United States Flunked the COVID-19 test: some observations and several lessons. The American Review of Public Administration, 2020.

51 Maani N, Galea S. COVID-19 and Underinvestment in the public health infrastructure of the United States. Milbank Q 2020;98:250-9.

52 Yates R. In the COVID-19 era, healthcare should be universal and free, 2020. Available: https://www.chathamhouse.org/expert/ comment/covid-19-era-healthcare-should-be-universal-and-free [Accessed 7 Aug 2020].

53 Gage A, Bauhoff S. Health systems in low-income countries will struggle to protect health workers from COVID-19. center for global development. Available: https://www.cgdev.org/blog/healthsystems-low-income-countries-will-struggle-protect-health-workerscovid-19 [Accessed 9 Aug 2020].

54 United Nations Comprehensive Response to COVID-19. Saving lives, protecting societies, recovering better, 2020. Available: https:// www.un.org/sites/un2.un.org/files/un_comprehensive_response_to_ covid-19_june_2020.pdf [Accessed 9 Aug 2020].

55 Siegfried K. UNHCR refugee Brief-27 March 2020, 2020. Available: https://www.unhcr.org/refugeebrief/the-refugee-brief-27-march2020/ [Accessed 9 Aug 2020].

56 Pūras D, de Mesquita JB, Cabal L, et al. The right to health must guide responses to COVID-19. Lancet 2020;395:1888-90.

57 Payne A. Spain has nationalized all of its private hospitals as the country goes into coronavirus lockdown, 2020. Available: https:// www.businessinsider.com/coronavirus-spain-nationalises-privatehospitals-emergency-covid-19-lockdown-2020-3 [Accessed 7 Aug 2020].

58 Nhs strikes major deal to expand Hospital capacity to battle coronavirus, 2020. Available: https://www.england.nhs.uk/2020/ 03/nhs-strikes-major-deal-to-expand-hospital-capacity-to-battlecoronavirus/ [Accessed 9 Aug 2020].

59 Shadmi E, Chen Y, Dourado I, et al. Health equity and COVID-19: global perspectives. Int J Equity Health 2020;19:104.

60 Holpuch A. Profit over people, cost over care: America's broken healthcare exposed by virus, 2020. Available: https://www. theguardian.com/us-news/2020/apr/16/profit-over-people-costover-care-americas-broken-healthcare-exposed-by-virus [Accessed 9 Aug 2020].

61 Leonhardt M. Uninsured Americans could be facing nearly $\$ 75,000$ in medical bills if hospitalized for coronavirus, 2020. Available: https://www.cnbc.com/2020/04/01/covid-19-hospital-bills-couldcost-uninsured-americans-up-to-75000.html [Accessed 9 Aug 2020].

62 ILO Monitor: COVID-19 and the world of work - Fifth edition, 2020. Available: https://www.ilo.org/wcmsp5/groups/public/-dgreports/dcomm/documents/briefingnote/wcms 749399.pdf [Accessed 8 Aug 2020].

63 Meier BM, Evans D, Phelan A. Rights-Based approaches to preventing, detecting, and responding to infectious disease. Infectious Diseases in the New Millennium 2020;82:217-53.

64 Alon T, Doepke M, Olmstead-Rumsey J. The impact of COVID-19 on gender equality. National Bureau of Economic Research, 2020. 
65 Wenham C, Smith J, Morgan R, et al. COVID-19: the gendered impacts of the outbreak. Lancet 2020;395:846-8.

66 Parmar I, Shah A. Who will foot the bill for COVID-19 bailouts? the much-derided public sector. Available: https://blogs.lse.ac.uk/ usappblog/2020/05/15/who-will-foot-the-bill-for-covid-19-bailoutsthe-much-derided-public-sector/ [Accessed 9 Aug 2020].

67 Gentilini U, Almenfi M, Dale P, et al. Social protection and jobs responses to COVID-19: a real-time review of country measures, 2020. Available: https://openknowledge.worldbank.org/handle/ 10986/33635; [Accessed 9 Aug 2020].

68 GOV.UK. Coronavirus (COVID-19): business support. Available: https://www.gov.uk/coronavirus/business-support [Accessed 9 Aug 2020].

69 New Zealand Government. COVID-19 wage subsidy ExtensionWork and income, 2020. Available: https://www.workandincome. govt.nz/covid-19/wage-subsidy-extension/index.html [Accessed 9 Aug 2020].

70 Australian Taxation Office. Support for businesses and employers. Available: https://www.ato.gov.au/General/COVID-19/Support-forbusinesses-and-employers/?default [Accessed 9 Aug 2020].

71 McMurtry A. Spain announces a \$220B stimulus package, 2020. Available: https://www.aa.com.tr/en/europe/spain-announces-a220b-stimulus-package/1769513 [Accessed 9 Aug 2020]

72 International Monetary Fund. Policy responses to COVID-19. Available: https://www.imf.org/en/Topics/imf-and-covid19/PolicyResponses-to-COVID-19 [Accessed 31 Jul 2020].

73 BBC News. Malawi's cash handouts and the row about a coronavirus lockdown, 2020. Available: https://www.bbc.com/news/ world-africa-52471276 [Accessed 9 Aug 2020].

74 S v President of Malawi and Others. Ex Parte: Kathumba and Others (Judicial Review Cause No. 22 of 2020) [2020] MWHC 7 (17 April 2020); The State on the application of Kathumba \& Ors $v$ The President \& Ors (Judicial Review Cause No. 22 of 2020) [2020] MWHC 8 (28 April 2020). Available: https://malawilii.org/mw/ judgment/high-court-general-division/2020/8

75 UN News. Water access critical to beating back COVID-19 spread in slum areas, 2020. Available: https://news.un.org/en/story/2020/03/ 1060042 [Accessed 9 Aug 2020]

76 United Nations. Shared responsibility, global solidarity: responding to the socio-economic impacts of COVID-19, 2020. Available: https://www.un.org/sites/un2.un.org/files/sg_report_socioeconomic impact of covid19.pdf [Accessed 8 Aug 2020].

77 Donnelly L. 'Parallel export' of essential drugs banned to protect UK in coronavirus outbreak, 2020. Available: https://www.telegraph. co.uk/news/2020/03/20/parallel-export-essential-drugs-bannedprotect-uk-coronavirus/ [Accessed 9 Aug 2020].

78 Eu moves to limit exports of medical equipment outside the bloc. POLITICO, 2020. Available: https://www.politico.eu/article/ coronavirus-eu-limit-exports-medical-equipment/ [Accessed 9 Aug 2020].

79 Memorandum on allocating certain scarce or threatened health and medical resources to domestic use. the white house, 2020. Available: https://www.whitehouse.gov/presidential-actions/ memorandum-allocating-certain-scarce-threatened-health-medicalresources-domestic-use/ [Accessed 9 Aug 2020].

80 Takian A, Raoofi A, Kazempour-Ardebili S. COVID-19 battle during the toughest sanctions against Iran. Lancet 2020;395:1035-6.

81 Universal Declaration of human rights (UDHR), G.A. Res. 217A (III), 1948. Available: http://www.un.org/en/documents/udhr

82 World Health Organization. International health regulations. 3rd edn, 2005.

83 GOV.UK. UK helps world's poorest countries withstand the economic disruption of coronavirus. Available: https://www.gov.uk/ government/news/uk-helps-worlds-poorest-countries-withstandthe-economic-shock-of-coronavirus [Accessed 9 Aug 2020].

84 UN. Global humanitarian response plan COVID-19: United nations coordinated appeal April - December 2020, 2020. Available: https:// www.unocha.org/sites/unocha/files/Global-Humanitarian-ResponsePlan-COVID-19.pdf [Accessed 8 Aug 2020].

85 UN Sustainable Development Group. A un framework for the immediate socio-economic response to COVID-19, 2020. Available: https://unsdg.un.org/resources/un-framework-immediate-socioeconomic-response-covid-19 [Accessed 8 Aug 2020].

86 World Health Organization. COVID-19 solidarity response fund for who. Available: https://covid19responsefund.org/en/ [Accessed 30 Jul 2020].

87 IMF. Joint remarks for the joint IMF/WHO conference. Available: https://www.imf.org/en/News/Articles/2020/04/03/sp040320opening-remarks-for-joint-imf-who-press-conference [Accessed 7 Apr 2020].

88 World Health Organization. COVID-19 technology access pool, 2020. Available: https://www.who.int/emergencies/diseases/novelcoronavirus-2019/global-research-on-novel-coronavirus-2019-ncov/ covid-19-technology-access-pool [Accessed 2 Jun 2020]

89 UNAIDS. World leaders unite in call for a people's vaccine against COVID-19 [Internet], 2020. Available: https://www.unaids.org/en/ resources/presscentre/pressreleaseandstatementarchive/2020/may/ 20200514_covid19-vaccine [Accessed 2 Jun 2020]. 